\title{
Impact of Waste Materials and Organic Amendments on Soil Properties and Vegetative Performance
}

\author{
Steven L. McGeehan \\ Department of Plant, Soil, and Entomological Sciences, University of Idaho, Moscow, ID 83844-2203, USA \\ Correspondence should be addressed to Steven L. McGeehan, mcgeehan@uidaho.edu
}

Received 1 June 2011; Accepted 20 October 2011

Academic Editor: Horea Cacovean

Copyright ( $) 2012$ Steven L. McGeehan. This is an open access article distributed under the Creative Commons Attribution License, which permits unrestricted use, distribution, and reproduction in any medium, provided the original work is properly cited.

\begin{abstract}
Waste materials, and materials derived from wastes, possess many characteristics that can improve soil fertility and enhance crop performance. These materials can be particularly useful as amendments to severely degraded soils associated with mining activities. This study evaluated biosolids, composts, log yard wastes, and two organic soil treatments for improved soil fertility and vegetative performance using side-by-side comparisons. Each plot was seeded with a standardized seed mix and evaluated for a series of soil chemical and physical parameters, total vegetation response, species diversity, ecological plant response, and invasion indices. All treatments were successful at improving soil fertility and promoting a self-sustaining vegetative cover. The level of available nitrogen had a strong impact on vegetative coverage, species distribution, and extent of unseeded vegetation. For example, high nitrogen treatments promoted a grass-dominated (low forb) plant community with a low content of unseeded vegetation. In contrast, low nitrogen treatments promoted a more balanced plant community with a mixture of grass and forb species and greater susceptibility to unseeded vegetation establishment.
\end{abstract}

\section{Introduction}

The use of waste materials as soil amendments has received increased attention in recent years for agronomic applications as well as soil reclamation projects. Adding these materials to soils can be viewed as serving a dual purpose: (1) for disposal of solid waste from municipalities and agricultural operations and (2) as a means to improve chemical and physical soil properties which in turn promotes improved crop performance.

A variety of materials have been investigated for their suitability as soil amendments. For example, applications of composted municipal solid waste and composted crop residues were shown to increase soil fertility and improve structural stability in agricultural soils $[1,2]$. Similarly, municipal biosolids have been used to improve soil chemical and physical properties in numerous studies [3-5]. Log yard fines (LYF) can increase water holding capacity and porosity [6] but have also been shown to reduce crop performance due to nitrogen immobilization [7]. For this reason, biosolids are often mixed with LYF and other wood byproducts as a means to reduce $\mathrm{C}: \mathrm{N}$ and maintain nitrogen availability $[8,9]$. Others have utilized agricultural limestone or wood ash in biosolids mixtures to reduce metal bioavailability $[3,10]$.

The chemical properties of the waste material can also have significant impacts on crop performance. For example, a high nitrogen content favors fast-growing grass species which is often desirable for reclamation and revegetation projects [11]. However, the dominance of grasses can lead to competitive exclusion of forb species [12] and can initiate a strong decline in plant species richness [10, 13]. Additional soil factors including $\mathrm{pH}$, electrical conductivity, water holding capacity, and available phosphorus have also been shown to impact plant community composition [14].

Several microbial processes including substrate-induced respiration, potential ammonium oxidation, nitrogen mineralization, and enzyme activity increased in response to compost application $[15,16]$. Multiple studies using a variety of substrates found no negative impacts on microbial diversity [16-18]. The potential does exist for deleterious impacts of 
organic waste additions, due primarily to the presence of heavy metals [19-21] and nutrient runoff [22, 23]. Many of these concerns are addressed by careful characterization of the waste material and through adjustment of the application rate $[24,25]$.

The above discussion indicates that a given waste material must be evaluated for both its beneficial components and negative impacts within the context of a specific land use and crop performance objective. Given the variety of waste material types available, it was desirable to conduct a side-byside comparison in order to evaluate each material's impact on crop performance under the same environmental and soil conditions. Furthermore, although multiple investigations have documented the impact of organic amendments in agricultural systems, far fewer studies have investigated these impacts in soil-plant systems associated with mine site reclamation. In many cases, mine spoils represent a completely destroyed soil-plant ecosystem. Restoration of these sites provides a unique opportunity to study the development of newly placed soils and associated succession of plant communities as modified by organic amendments. In the current study, seven waste-based and organic soil amendments were evaluated for their impacts on soil fertility and crop performance. The "crop" in this case was a grassforb seed mix being evaluated for revegetation of the severely degraded site. Specific research objectives were to document (1) changes in soil properties, (2) overall vegetation success, and (3) plant community diversity as a function of organic amendment.

\section{Methods}

2.1. Site Description. The Silver Dollar Mine site is located west of Osburn, Idaho, USA $\left(47^{\circ} 30.22^{\prime} \mathrm{N} ; 115^{\circ} 59.39^{\prime} \mathrm{W}\right)$. The site is dominated by a waste rock pile produced during mine development and sorted from the ore during the mining process. The experimental plots were situated on a steep north-facing slope $(1: 2$ slope, $\mathrm{H}: \mathrm{V})$ at an elevation of about $760 \mathrm{~m}$. Average total monthly precipitation ranged from $3.8 \mathrm{~cm}$ in July to $11.4 \mathrm{~cm}$ in November, with a total annual precipitation of $96 \mathrm{~cm}$. Average monthly temperatures were $0.5 /-6^{\circ} \mathrm{C}(\mathrm{max} / \mathrm{min})$ in January and $25.8 / 8.4^{\circ} \mathrm{C}$ in August.

2.2. Site Preparation/Plot Installation. The site was regraded using a Cat D5 Dozer, and nine plots $(6 \mathrm{~m} \times 30.5 \mathrm{~m})$ were installed with a berm $(1 \mathrm{~m} \times 0.6 \mathrm{~m})$ separating each plot. The western- and eastern-most plots were reserved for controls; the remaining plots were assigned on a random basis. Amendment types, application rates, and application methods were specified by the collaborators participating in the study (Table 1). Project collaborators included the local wastewater treatment facility (biosolids + woodash), a local lumber mill (log yard fines (LYF) + urea fertilizer), and two commercial composts (biosolids- and wood productsbased). In addition, two commercial organic amendments were investigated. Kiwi Power is designed to reestablish mycorrhizal fungi, soil bacteria, and other beneficial soil organisms necessary to restore severely degraded soils. Biosol
TABLE 1: Amendment type, application rates, and application methods.

\begin{tabular}{|c|c|}
\hline Amendment type & Rate and application method \\
\hline Control (topsoil) & $\begin{array}{l}30 \mathrm{~m}^{3} \text { topsoil (surface applied, not } \\
\text { incorporated, amendment depth approx. } \\
15 \mathrm{~cm} \text { ) }\end{array}$ \\
\hline $\begin{array}{l}\text { Biosolids + } \\
\text { woodash }\end{array}$ & $\begin{array}{l}20 \mathrm{~m}^{3} \text { class B biosolids mixed with wood } \\
\text { ash }(0.75: 1) \text { (surface applied, not } \\
\text { incorporated, amendment depth approx. } \\
10 \mathrm{~cm})\end{array}$ \\
\hline $\begin{array}{l}\text { Log yard fines } \\
\text { (LYF) + urea } \\
\text { fertilizer }\end{array}$ & $\begin{array}{l}37 \mathrm{~m}^{3} \log \text { yard fines }\left(<3 / 4^{\prime \prime}\right) \text { mixed with } \\
\text { urea fertilizer }(10 \% \mathrm{v} / \mathrm{v})(\text { surface applied, } \\
\text { not incorporated, amendment depth } \\
\text { approx. } 15 \mathrm{~cm})\end{array}$ \\
\hline Kiwi Power & $\begin{array}{l}\text { Fertile Fibers Plus, Kiwi Power, Strong } \\
\text { Hold + Tacker and Atlas Soil Lock } \\
\text { (materials were mixed and surface } \\
\text { applied by hydroseeder) }\end{array}$ \\
\hline $\begin{array}{l}\text { Biosolids-based } \\
\text { compost }\end{array}$ & $\begin{array}{l}15 \mathrm{~m}^{3} \text { of compost (surface applied, not } \\
\text { incorporated, amendment depth approx. } \\
10 \mathrm{~cm} \text { ) }\end{array}$ \\
\hline $\begin{array}{l}\text { Wood } \\
\text { products-based } \\
\text { compost }\end{array}$ & $\begin{array}{l}15 \mathrm{~m}^{3} \text { of compost (surface applied, not } \\
\text { incorporated, amendment depth approx. } \\
10 \mathrm{~cm} \text { ) }\end{array}$ \\
\hline Biosol & $\begin{array}{l}38 \mathrm{~kg} \text { Biosol Mix (7-2-3) plus } 2.3 \mathrm{~kg} \\
\text { Wood Fiber Mulch (materials were mixed } \\
\text { and surface applied by hydroseeder) }\end{array}$ \\
\hline $\begin{array}{l}\text { Log yard waste } \\
\text { (LYW) }\end{array}$ & $\begin{array}{l}15 \mathrm{~m}^{3} \text { of } \log \text { yard waste (surface applied, } \\
\text { not incorporated, amendment depth } \\
\text { approx. } 10 \mathrm{~cm} \text { ) }\end{array}$ \\
\hline Control (fertilizer) & $\begin{array}{l}23 \mathrm{~kg} \text { of fertilizer (16-16-16) plus tackifier } \\
\text { (materials were mixed and surface } \\
\text { applied by hydroseeder) }\end{array}$ \\
\hline
\end{tabular}

is an organic fertilizer material designed to increase microbial biomass and build humus. Installation of the plots began September 25, 2002 and concluded October 23, 2002. Each plot was seeded, either by hand or by hydroseeding, using a standardized seed mix (Table 2). No additional work, modification, or maintenance was conducted on the plots for the remainder of the five-year study with one exceptionthe LYF + urea plot was reseeded in August 2003. This was necessary due to a complete failure of seed germination in year 1 .

2.3. Soil and Vegetation Assessment. The plots were inspected on a monthly basis during each field season beginning in April 2003 and concluding in August 2007. Quantitative determination of revegetation success was conducted each July using Bureau of Land Management standard methods [26]. Percent coverage was measured using a cover-point optical projection scope. One hundred points were recorded at $1 \mathrm{~m}$ intervals along a randomly located transect within each plot. Each point identified an individual plant, rock, bare soil, or litter.

Duplicate soil samples were collected from the control plots following regrading but prior to addition of plot 
TABLE 2: Composition and application rates of standardized seed mix.

\begin{tabular}{|c|c|c|c|c|}
\hline Common name & Species/variety & Amount/acre & Pct by wt. & Min. pct. \\
\hline Slender wheatgrass & Elymus trachycaulus ssp. Trachycaulus var. Revenue & $6.4 \mathrm{~kg}$ & 22.3 & 21.9 \\
\hline Idaho fescue & Festuca idahoensis var. Joseph & $3.9 \mathrm{~kg}$ & 13.4 & 13.2 \\
\hline Sheep fescue & Festuca ovina var. Covar & $3.2 \mathrm{~kg}$ & 11.1 & 10.9 \\
\hline Mountain brome & Bromus marginatus var. Bromar & $3.5 \mathrm{~kg}$ & 12.2 & 12.0 \\
\hline Meadow brome & Bromus biebersteinii var. Paddock & $3.9 \mathrm{~kg}$ & 13.4 & 13.2 \\
\hline White yarrow & Achillea millefolium & $0.34 \mathrm{~kg}$ & 1.1 & 1.1 \\
\hline Blue flax & Linum lewisii var. Appar & $1.9 \mathrm{~kg}$ & 6.7 & 6.6 \\
\hline Rocky Mountain penstemon & Penstemon strictus & $0.68 \mathrm{~kg}$ & 2.2 & 2.2 \\
\hline White dutch clover & Trifolium repens $\mathrm{L}$. & $0.23 \mathrm{~kg}$ & 0.8 & 0.8 \\
\hline Canada bluegrass & Poa compressa & $0.34 \mathrm{~kg}$ & 1.1 & 1.1 \\
\hline Big bluegrass & Poa ampla var. Sherman & $0.68 \mathrm{~kg}$ & 2.3 & 2.3 \\
\hline Canby bluegrass & Poa canbyi var. Canbar & $0.68 \mathrm{~kg}$ & 2.2 & 2.2 \\
\hline Cicer milkvetch & Astragalus cicer & $3.2 \mathrm{~kg}$. & 11.1 & 10.9 \\
\hline Fireweed & Epilobium angustifolia & $0.28 \mathrm{~kg}$ & 0.1 & 0.1 \\
\hline Weed seed & - & - & - & 0.5 (Max) \\
\hline Inert and other crop & 一 & - & 一 & 1.5 (Max) \\
\hline
\end{tabular}

amendments; these results are reported as the control (unamended) in the following figures and tables. Soil profile characteristics were evaluated in the field at the end of year 5 . During years 1,3 , and 5 , a composite $(3 \mathrm{x})$ soil sample was collected from the $0-10 \mathrm{~cm}$ depth of each plot. Soil fertility parameters (ammonium-N, nitrate- $\mathrm{N}$, available $\mathrm{P}$ and $\mathrm{K}, \mathrm{pH}$, and $\mathrm{EC}$ ) and physical properties (percent sand, silt, clay, coarse fragments, and textural class) were determined using standard methods [27]. Available N was calculated as the sum of ammonium- and nitrate-N. Organic matter content was determined by colorimetry [28]. Total recoverable metals were determined using EPA Method $3050 \mathrm{~B} / 6010$ [29]. All laboratory work was conducted at the University of Idaho Analytical Sciences Laboratory. Standard quality assurance/quality control protocols were followed for all analytical work [30].

2.4. Data Analysis. Diversity-related indices, namely Shannon-Wineer index $\left(\mathrm{H}^{\prime}\right)$ and evenness $(\mathrm{E})$, were calculated by year for each treatment. The invasion index (I) was also calculated for each treatment where $I$ is the number of introduced species/total number of species. Diversity indices and plant cover data were subjected to analysis of variance using the generalized linear model [31]. Single degree of freedom contrasts were used to compare mean responses. A 95\% significance level $(P<0.05)$ was used for all statistical comparisons.

\section{Results and Discussion}

3.1. Soil and Amendment Properties. Following site preparation but prior to amendment application, the surface soil material was a mixture of waste rock and fine material. The unamended control (Table 3) exhibited properties endemic to the Silver Dollar site, namely an alkaline ( $\mathrm{pH} 8.3$ ) sandy loam with $58 \%$ coarse fragments. The electrical conductivity (EC) of the unamended control was $0.35 \mathrm{dS} / \mathrm{m}$ and heavy metal concentrations ( $\mathrm{As}, \mathrm{Ba}, \mathrm{Cd}, \mathrm{Cr}, \mathrm{Pb}$ ) were below hazard limits for regulated metals [32]. This is not surprising since milling and smelting activities took place off-site. The macronutrient content of the unamended control was quite low with available $\mathrm{N}$ and $\mathrm{P}$ concentrations of $1.5 \mathrm{ug} / \mathrm{g}$ and $1.0 \mathrm{ug} / \mathrm{g}$, respectively (Figure 1). Organic matter content was also low at $0.9 \%$ and available $\mathrm{K}$ was moderate at $79 \mathrm{ug} / \mathrm{g}$. Thus, the chemical and physical data indicate that low soil fertility was the primary factor limiting sustainable plant growth in the unamended soil. A secondary issue was the low water holding capacity.

Each treatment decreased soil $\mathrm{pH}$ relative to the unamended control (Table 3 ). The $\mathrm{pH}$ of the amended plots ranged from 6.3 to 7.8 with the biosolid + woodash and control (fertilizer) treatments exhibiting the highest $\mathrm{pH}$. Overall, the $\mathrm{pH}$ remained relatively consistent among the amended plots throughout the five-year study period (data not shown). The highest EC values were observed in the biosolids + woodash and LYF + urea treatments (Table 3 ). Although these higher EC values are near critical values for agronomic crops $(2-4 \mathrm{dS} / \mathrm{m})$, none of the vegetation exhibited symptoms of a salinity problem.

During the first year (2003), the organic matter content varied from $\sim 1 \%$ in the controls and liquid-based amendments (Kiwi Power and Biosol) to $15-34 \%$ in the solidbased amendments (biosolid, composts, LYF, and LYW) (Figure 1(a)). The organic matter content in several of the treatments (biosolids, LYF + urea, and biosolids-compost) increased between 2003 and 2005 (Figure 1(a)). Each of these treatments exhibited substantial vegetative growth resulting in high crop residues and organic carbon recycling. Each treatment associated with the high organic matter amendment (biosolid, composts, LYF, and LYW) exhibited a marked decrease in organic matter between 2005 and 2007.

Each treatment increased the available $\mathrm{P}$ and $\mathrm{K}$ content with the extent of increase being strongly dependent on 


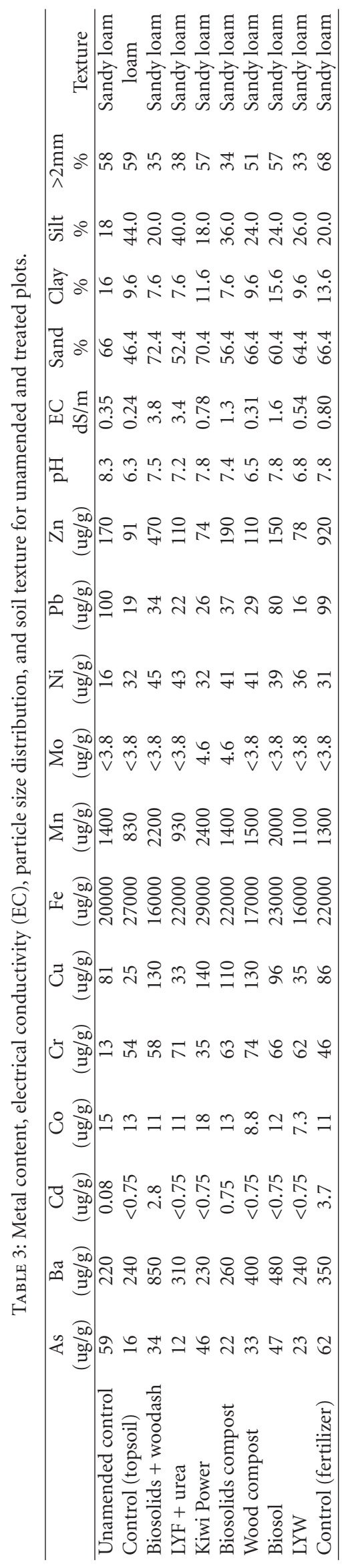




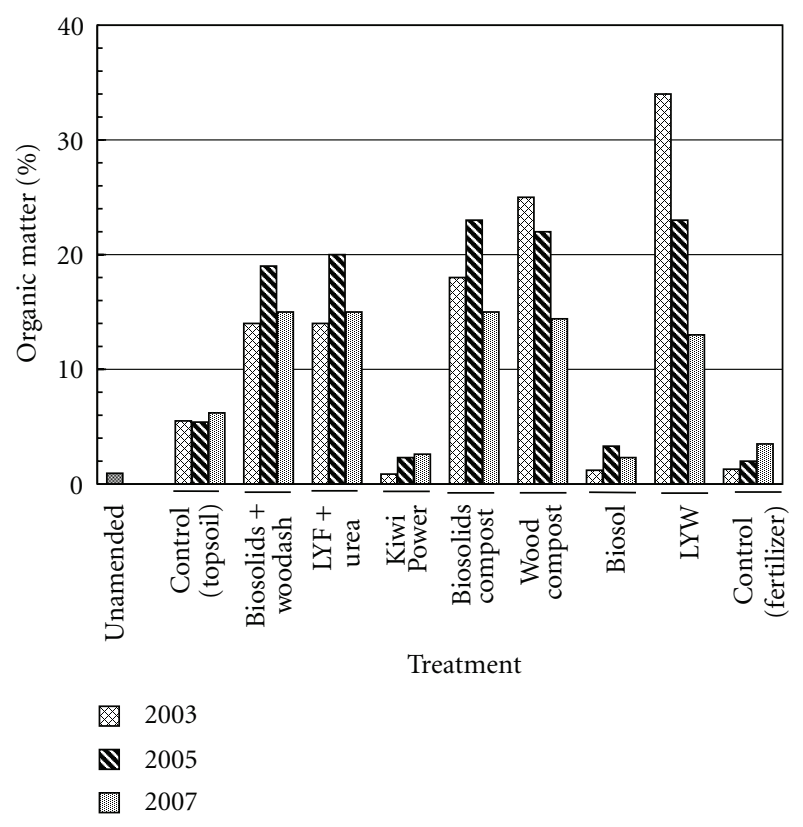

(a)

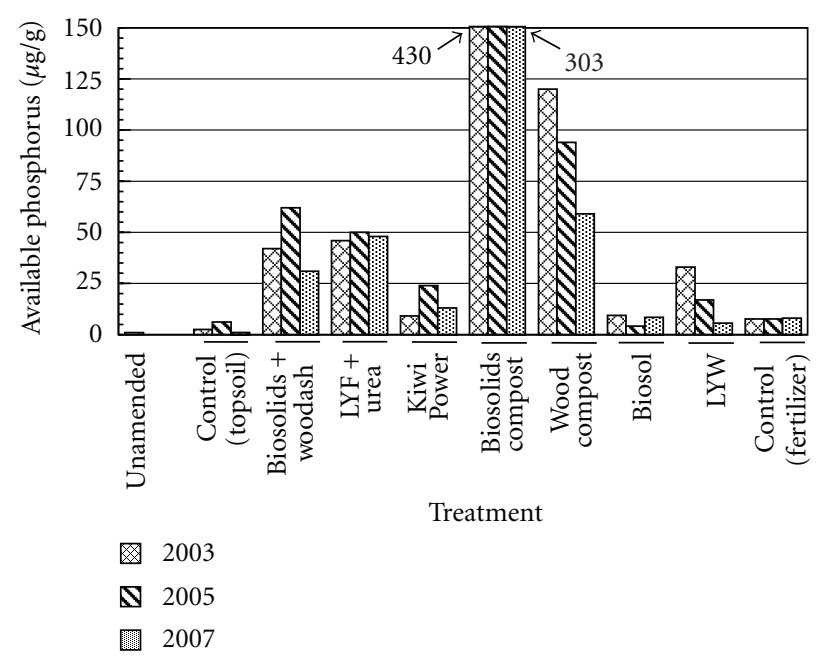

(c)

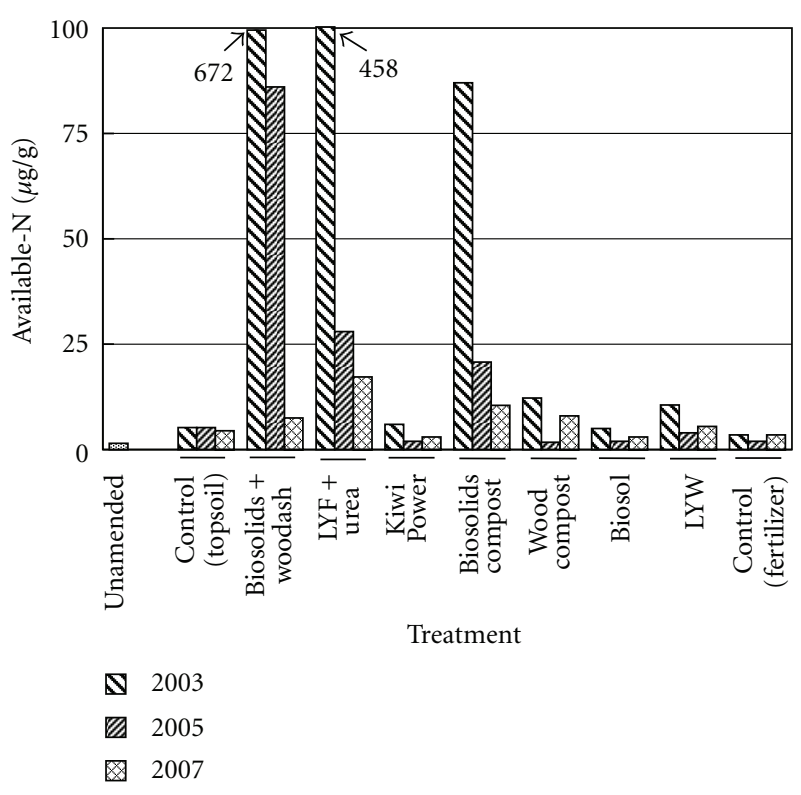

(b)

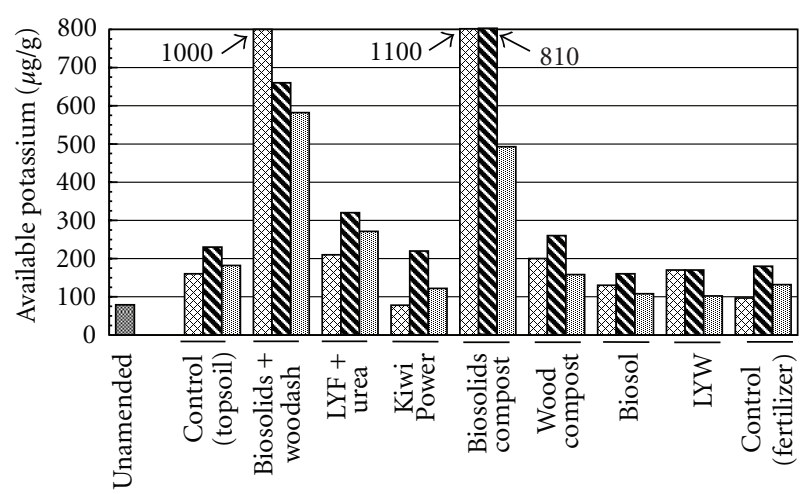

Treatment

図 2003

2005

2007

(d)

FIgURE 1: Trends in (a) organic matter content, (b) available N, (c) available phosphorus, and (d) available potassium in the unamended and treated plots for years 2003, 2005, and 2007.

the nature of the amendment (Figures $1(\mathrm{c})$ and $1(\mathrm{~d})$ ). Available $P$ values ranged from $<2$ to $>600 \mathrm{ug} / \mathrm{g}$ while available $\mathrm{K}$ ranged from 80 to $1000 \mathrm{ug} / \mathrm{g}$. To put these numbers into perspective, available $\mathrm{P}$ and $\mathrm{K}$ levels in excess of 8 and $100 \mathrm{ug} / \mathrm{g}$, respectively, are considered sufficient for nonirrigated legume-grass pastures in northern Idaho [33].

Available $\mathrm{N}$ also varied significantly among the treatments, ranging from $\sim 5 \mathrm{ug} / \mathrm{g}$ in the Kiwi Power and Biosol to $>450 \mathrm{ug} / \mathrm{g}$ in the biosolids and LYF + urea treatments (Figure 1(b)). Each treatment with high available $\mathrm{N}$ (biosolid, biosolid-compost, and LYF + urea) exhibited a substantial decrease between 2003 and 2005, and again between 2005 and 2007. Potential fates of available
$\mathrm{N}$ include leaching, plant uptake, and volatilization. A significant fraction of available $\mathrm{N}$ was lost via surface runoff as previously described by McGeehan [34] and this was most significant in the biosolids + woodash, LYF + urea, and biosolids-compost treatments. The high available $\mathrm{N}$ associated with these plots also supported very heavy vegetative growth, primarily of perennial grasses which exhibit high uptake rates and $\mathrm{N}$ sequestration $[35,36]$. However, given the magnitude of declines observed, it is likely that ammonia volatilization played the most significant role in decreased available N. Large and rapid loss of $\mathrm{N}$ is commonly observed in surface-applied biosolids with volatilization rates exceeding $50 \%$ of total $\mathrm{N}$ [37-39]. 
This mechanism was further enhanced by the high $\mathrm{pH}$ levels.

3.2. Profile Properties. The addition of the various amendments had differing impacts on the soil profile of each plot. It should be noted that a true pedogenic soil profile takes hundreds to thousands of years to form. Thus, it is somewhat of a stretch to describe the profile of each plot using standard soils terminology. Nonetheless, the amendments did alter the surface properties of each plot in ways that will have lasting impacts on the sustainability of the plant cover. For example, the addition of roughly $20 \mathrm{~m}^{3}$ of biosolids, compost, or log yard waste resulted in an overburden depth of $10-15 \mathrm{~cm}$. This overburden tended to be dark in color with a very friable (easily crumbled) texture. Such characteristics are associated with highly productive and fertile topsoil and, hence, these plots supported very good plant growth resulting in the presence of profuse fine roots in the overburden. Since the organic materials were surface applied but not incorporated, there was an abrupt boundary between the overburden and underlying waste rock with very few roots penetrating this boundary. This abrupt boundary remained very distinct throughout the study. Also, the physical condition of the overburden improved over the course of the 5-year study. For example, the biosolids were very sticky and tended to smear during application. However, as this material dried and weathered for several years, the result was a very light material with physical properties that are ideal for plant growth. Likewise, the log yard waste and composts underwent both physical and biological weathering, resulting in a very friable material with excellent tilth and other desirable physical properties.

In contrast, the Kiwi Power, Biosol, and Fertilizer Control did not receive large quantities of organic amendments. Consequently, these plots exhibited a thin organic surface layer developed from decaying plant debris. Despite the lack of a thick, organic overburden, these plots still supported good plant growth as evidenced by the moderate root presence. It is likely that these plots will continue to build organic matter content over time and slowly improve soil physical properties.

\subsection{Vegetation Assessment}

3.3.1. Plant Cover. Each treatment was successful in promoting a self-sustaining plant cover during 2003 and maintaining plant growth throughout the five-year study (Figure 2). During the first year, the extent of coverage varied considerably, ranging from $19 \%$ to $77 \%$ in the LYW and biosolid-compost treatments, respectively. The woodcompost treatment exhibited low coverage in year 1 , most likely as a result of a high $\mathrm{C}: \mathrm{N}$. Plant coverage increased in all treatments between years 1 and 2. These changes were associated with increased growth of grass species in the biosolids + woodash, biosolids compost, and Biosol plots and increased forb growth in the Kiwi Power, wood compost, and LYW plots. Slender wheatgrass and brome species were the most extensive grasses observed during years
1 and 2 while yarrow and white dutch clover were the most frequently observed forbs. The majority of plots maintained plant coverage in the $75-90 \%$ range from year 3 to year 5 (Figure 2).

3.3.2. Unseeded Vegetation. Unseeded vegetation accounted for a significant portion of coverage in several treatments during the study period (Figure 2). For example, the topsoilcontrol exhibited a high incidence of weeds beginning in year 1 with $>50 \%$ of the plant cover due to the establishment and growth of hare's foot clover. In contrast, the Kiwi Power, wood compost, and LYW plots did not exhibit substantial increases in weeds until years 3 and 4 (Figure 2). These large increases were primarily the result of black medic and sweet clover. It should be noted that several plots (i.e., biosolids + woodash, LYF + urea, biosolids compost, and Biosol) exhibited very little weed invasion. The majority of the unseeded species can be classified as common weeds of the Northwestern US [40] that are easily disseminated by wind, animals, and other vectors. However, given the disproportionately high percentage of unseeded vegetation present in the topsoil-control in year 1, it is likely that many weed seeds were transported to the site in the topsoil amendment. The role of topsoil as a seed bank is well established, and imported soil has been reported to introduce both desirable and undesirable invasive species $[41,42]$.

3.3.3. Species Distribution and Diversity. Grass species dominated the plant communities in the high $\mathrm{N}$ treatments. As an example, the species composition by year for the biosolids + woodash treatment is plotted in Figure 3(a). Similar results were obtained for the LYF + urea and biosolidcompost treatment. Although wheatgrass was the dominant grass in year 1, the 2004-2007 data (years 2-5) show a trend of declining wheatgrass with concurrent increases in bromes and fescues in of the grass-dominated plots. It is unclear whether the gradual decline in wheatgrass is a natural successional characteristic or a response of this species to a decrease in available $\mathrm{N}$. The lower $\mathrm{N}$ treatments exhibited a more even distribution between grass and forb species throughout the study period. As an example, species composition for the wood-compost is plotted in Figure 3(b). Similar results were obtained for the Kiwi Power and LYW treatments. Yarrow, fescue, and bromes tended to increase steadily in years 1,2 , and 3 . White clover was common on several of the lower $\mathrm{N}$ treatments in year 1 but was rarely encountered during years $2-5$. In contrast, cicer milkvetch was not observed during years 1 and 2 but increased significantly during the final three years of the study.

The relationship between vegetation and $\mathrm{N}$ availability was further evaluated by pooling the plant response data into high versus low treatments for statistical analysis. As shown in Figure 4(a), significantly higher Shannon diversity indices $\left(\mathrm{H}^{\prime}\right)$ were obtained for the high $\mathrm{N}$ treatments in three out of the five study years. This reflects the greater number of grass species associated with these treatments, particularly in the final two years. Species evenness (E) was very similar between the high and low $\mathrm{N}$ treatments (Figure 4(b)) 


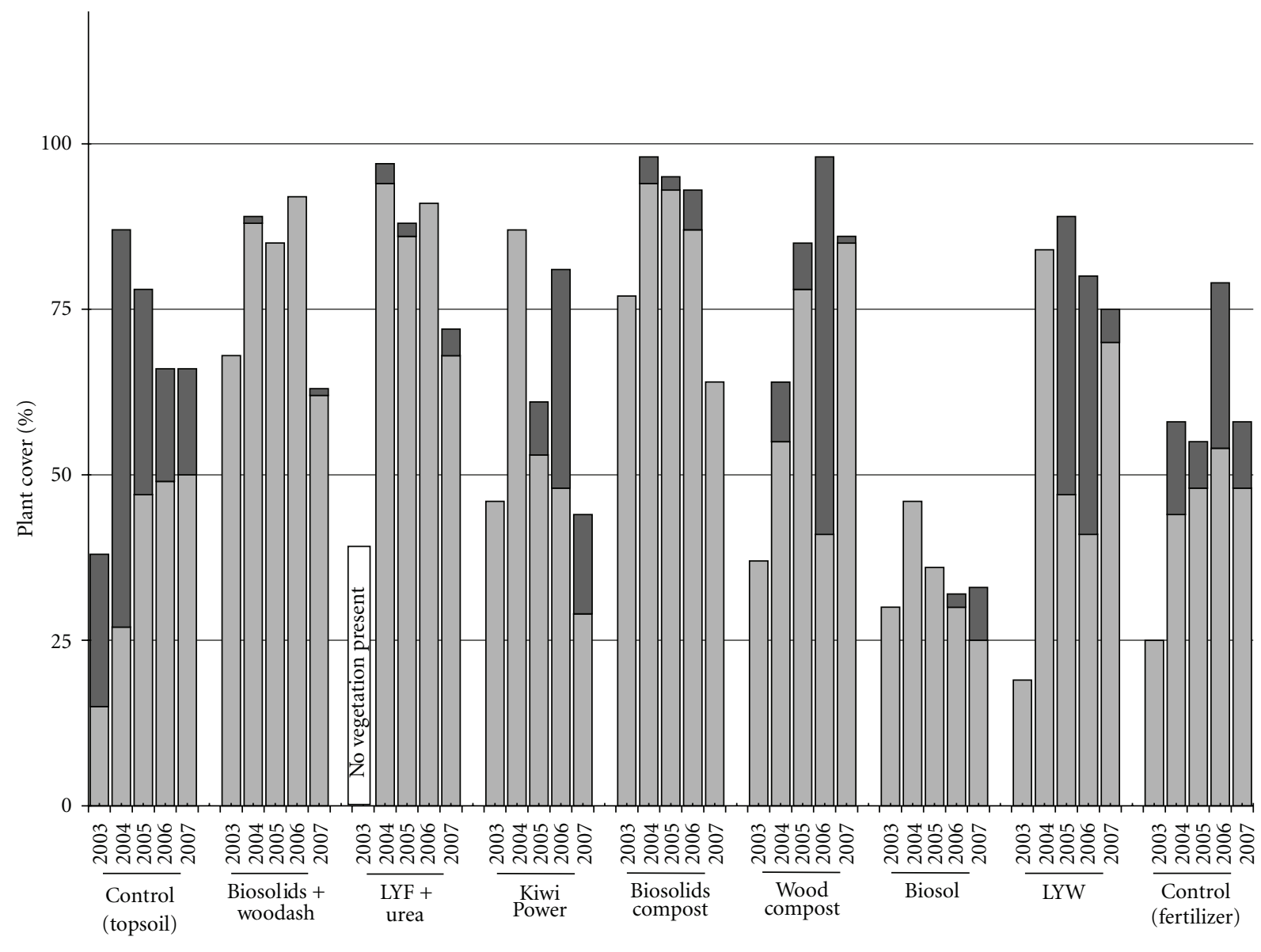

Treatment

- Unseeded vegetation

$\square$ Seeded vegetation

FigURE 2: Comparison of total plant cover across all treatments for years 2003, 2004, 2005, 2006, and 2007.

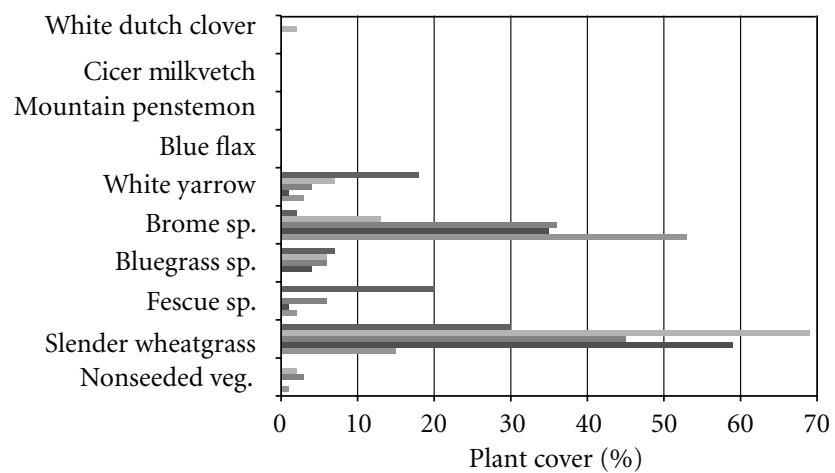

(a)

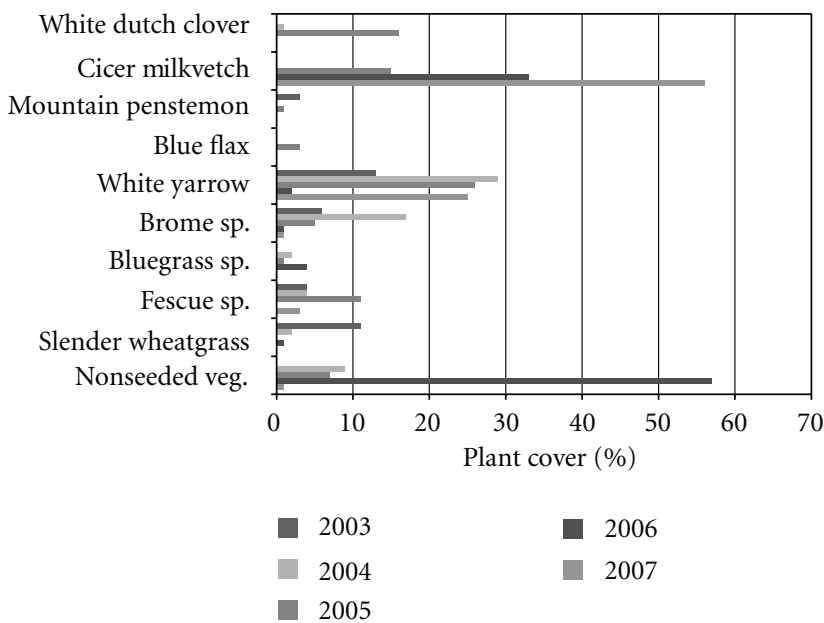

(b)

FIGURE 3: Species composition on (a) high nitrogen treatment (biosolids + woodash) and (b) low nitrogen treatment (wood compost) for years 2003, 2004, 2005, 2006, and 2007. 


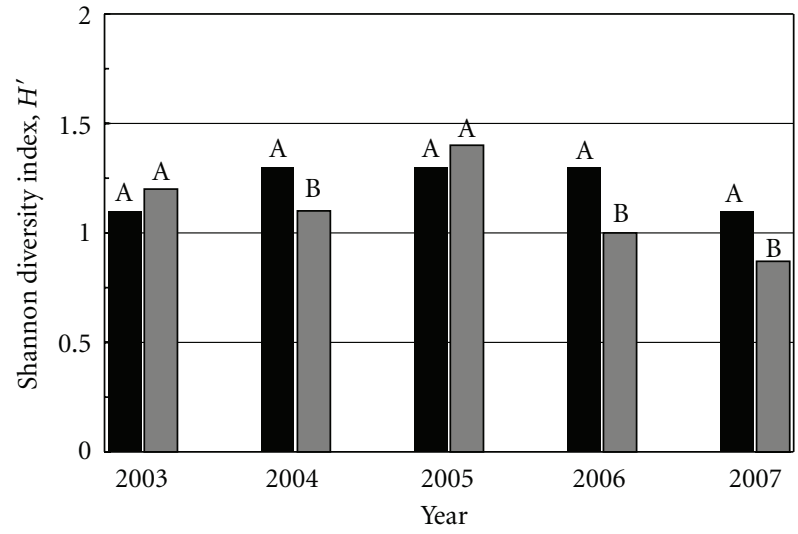

(a)

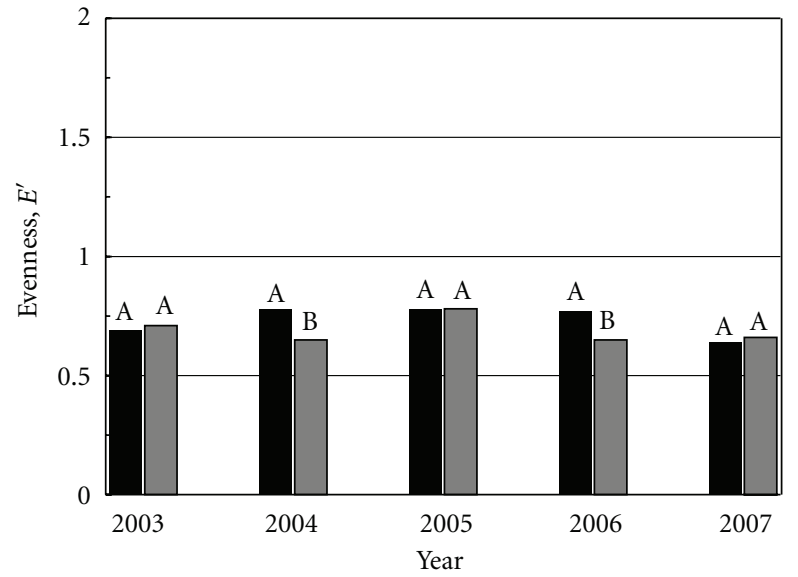

High $\mathrm{N}$

$\square$ Low $\mathrm{N}$

(b)

Figure 4: Mean responses for (a) Shannon diversity index and (b) species evenness in pooled high versus low nitrogen treatments by year. Responses associated with different letters are significantly different $(P<0.05)$.

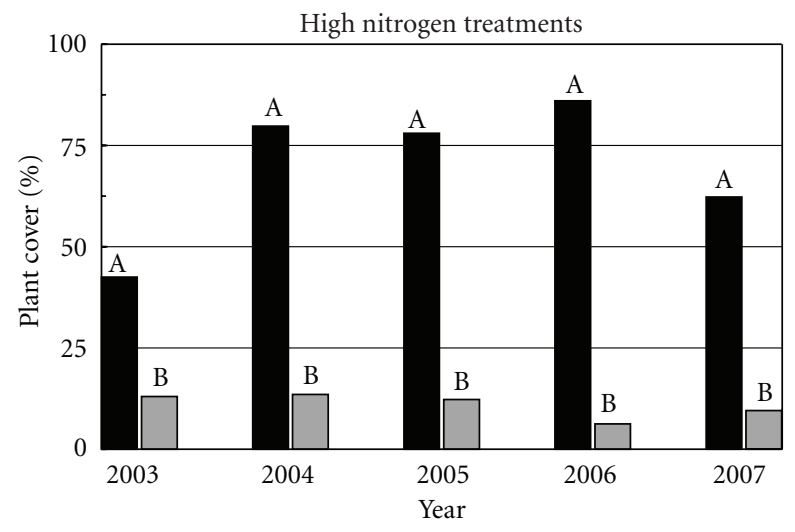

(a)

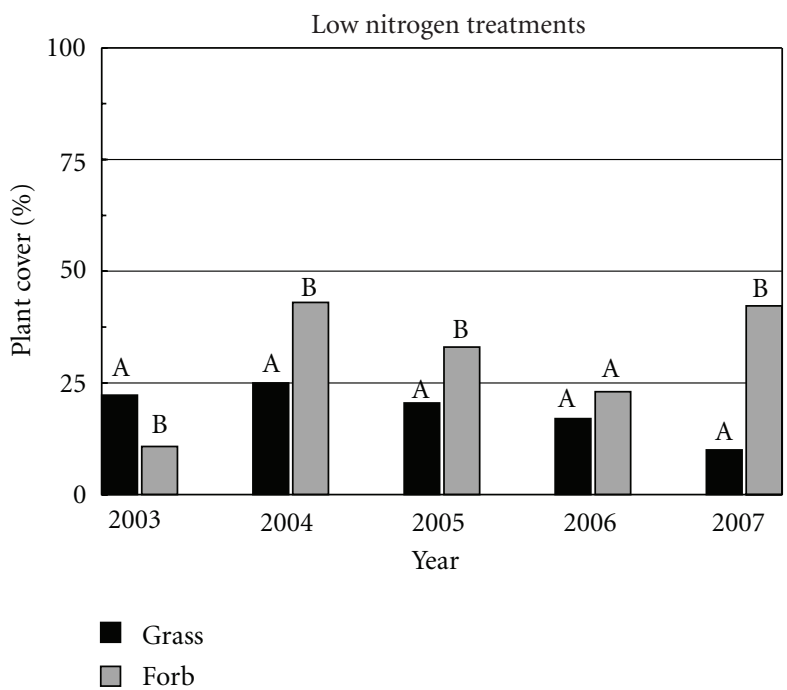

(b)

FIGURE 5: Mean vegetation response in (a) pooled high nitrogen treatments and (b) pooled low nitrogen treatments by year. Responses associated with different letters are significantly different $(P<0.05)$.

indicating no significant differences in the relative abundance of species between these groups, with the exception of 2006.

A comparison of vegetative response based on ecological vegetative groupings (grass versus forb) is shown in Figure 5. In each of the five years, the percent cover due to grasses was significantly higher than forb cover in the pooled high $\mathrm{N}$ treatments (Figure 5(a)). In contrast, forbs were significantly higher in 3 of 5 years in the low $\mathrm{N}$ treatments. Furthermore, the invasion index (I) was markedly impacted by $\mathrm{N}$ treatment. Counts of weed species were very low in the first two years of the study but increased substantially in the low $\mathrm{N}$ treatments in Years 3, 4, and 5 (Figure 6).

Several studies report increased weed growth in high nitrogen environments $[43,44]$. The opposite trend was observed in our study where, as Figure 6 clearly shows, an inverse relationship exists between available nitrogen and the invasion index. That is, a low invasion index is associated with the high $\mathrm{N}$ treatments and vice versa. A likely mechanism explaining this result is a competition for 


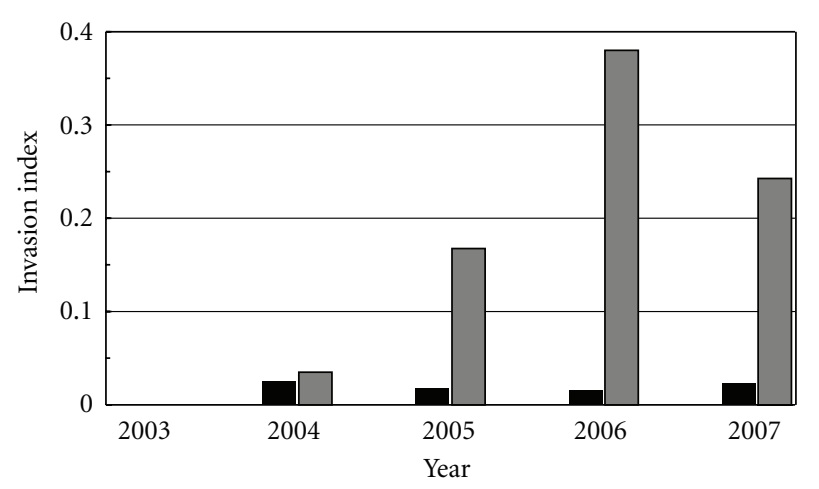

- High $\mathrm{N}$

$\square$ Low $\mathrm{N}$

FIGURE 6: Mean invasion indices in pooled high- versus low-pooled nitrogen treatments by year. Note: the number of zero values precluded statistical analysis.

nutrients and light which can favor rapidly growing grasses $[45,46]$. The growth habit of the weed species may be an additional factor with low, radially spreading species being less able to compete for light and, hence, be favored by the more open cover of the low nitrogen treatments [47].

\section{Conclusions}

The overall goal of this study was to evaluate waste-based and organic amendments for their ability to improve soil fertility and crop performance. Each amendment resulted in significant improvements in soil fertility parameters and all were successful in establishing plant cover during the first growing season and sustaining this cover throughout the five-year study.

Organic matter content and available N, P, and $\mathrm{K}$ were significantly increased by the various amendments although the extent of increase was determined by the composition of the amendment. All solid amendment types (composts, biosolids, and LYF/LYW) greatly increased the organic matter content. However, only the biosolids, biosolid-based compost, and LYF mixed with urea fertilizer contributed large amounts of available N. The wood products-based compost and LYF contributed lower amounts of available $\mathrm{N}$. Each treatment associated with high inputs of organic matter and available $\mathrm{N}$ exhibited significant declines in these properties over the course of the study.

The fertility status of each amendment had a strong impact on crop performance. More specifically, available nitrogen was a critical factor in determining total plant cover, species distribution, and the incidence of unseeded vegetation. For example, high nitrogen amendments promoted a grass-dominated cover with low numbers of forbs. Wheatgrass was the dominant species in these plots during years 1 and 2 but a more equal distribution of wheatgrass, bromes, fescues, and bluegrass was observed in years 35. Throughout the study, these plots had the highest plant coverage and maintained very robust and thick grass growth.
These characteristics were successful in preventing the establishment and spread of invasive weed species. In contrast, amendments with lower available nitrogen promoted a more diverse grass-forb mixture. No single grass species was dominant; instead a variety of grasses were intermixed with white yarrow, white clover, and cicer milkvetch. These plots had lower plant coverage and more patchy plant growth. Consequently, a higher incidence of invasive weed species was observed.

\section{Acknowledgments}

The author is grateful to Nick Zilka and John Lawson of the Idaho Department of Environmental Quality, Jerrry Lee and Tom Borque of TerraGraphics Environmental Engineering, and Mark Stannard of the USDA-NRCS for their support of this project and the helpful discussions. He appreciates the invaluable help of Dr. William Price with the statistical analyses. He also thanks the project collaborators: Don Keil (Coeur d'Alene Wastewater Treatment Plant), Bernie Wilmarth (Potlatch Corp.), Peter McRae (Quattro Environmental, Inc.), Joe Jackson (Eko Compost), David Larson (Glacier Gold, LLC), and Tom Bowman (Rocky Mountain Bio Products); this project would not have been possible without their participation.

\section{References}

[1] J. Weber, A. Karczewska, J. Drozd et al., "Agricultural and ecological aspects of a sandy soil as affected by the application of municipal solid waste composts," Soil Biology and Biochemistry, vol. 39, no. 6, pp. 1294-1302, 2007.

[2] M. Tejada, M. T. Hernandez, and C. Garcia, "Soil restoration using composted plant residues: effects on soil properties," Soil and Tillage Research, vol. 102, no. 1, pp. 109-117, 2009.

[3] Y. M. Li, R. L. Chaney, G. Siebielec, and B. A. Kerschner, "Response of four turfgrass cultivars to limestone and biosolids-compost amendment of a zinc and cadmium contaminated soil at Palmerton, Pennsylvania," Journal of Environmental Quality, vol. 29, no. 5, pp. 1440-1447, 2000.

[4] K. Debosz, S. O. Petersen, L. K. Kure, and P. Ambus, "Evaluating effects of sewage sludge and household compost on soil physical, chemical and microbiological properties," Applied Soil Ecology, vol. 19, no. 3, pp. 237-248, 2002.

[5] F. García-Orenes, C. Guerrero, J. Mataix-Solera, J. NavarroPedreño, I. Gómez, and J. Mataix-Beneyto, "Factors controlling the aggregate stability and bulk density in two different degraded soils amended with biosolids," Soil and Tillage Research, vol. 82, no. 1, pp. 65-76, 2005.

[6] M. Zeng, A. G. Campbell, and R. L. Mahler, "Log yard fines as a soil amendment: pot and field studies," Communications in Soil Science and Plant Analysis, vol. 24, no. 15-16, pp. 20252041, 1993.

[7] A. G. Campbell, R. L. Folk, and R. R. Tripepi, "Amended and composted log yard fines as a growth medium for crimson clover and red top grass," Communications in Soil Science and Plant Analysis, vol. 25, no. 13-14, pp. 2439-2454, 1994.

[8] S. L. Brown, C. L. Henry, R. Chaney, H. Compton, and P. S. DeVolder, "Using municipal biosolids in combination with 
other residuals to restore metal-contaminated mining areas," Plant and Soil, vol. 249, no. 1, pp. 203-215, 2003.

[9] C. Bulmer, K. Venner, and C. Prescott, "Forest soil rehabilitation with tillage and wood waste enhances seedling establishment but not height after 8 years," Canadian Journal of Forest Research, vol. 37, no. 10, pp. 1894-1906, 2007.

[10] S. Brown, M. Sprenger, A. Maxemchuk, and H. Compton, "Ecosystem function in alluvial tailings after biosolids and lime addition," Journal of Environmental Quality, vol. 34, no. 1, pp. 139-148, 2005.

[11] T. D. Glanville, R. A. Persyn, T. L. Richard, J. M. Laflen, and P. M. Dixon, "Environmental effects of applying composted organics to new highway embankments: part 2. Water quality," Transactions of the American Society of Agricultural Engineers, vol. 47, no. 2, pp. 471-478, 2004.

[12] J. O. Mountford, K. H. Lakhani, and F. W. Kirkham, "Experimental assessment of the effects of nitrogen addition under hay-cutting and aftermath grazing on the vegetation of meadows on a Somerset peat moor," Journal of Applied Ecology, vol. 30, no. 2, pp. 321-332, 1993.

[13] J. P. Bakker and F. Berendse, "Constraints in the restoration of ecological diversity in grassland and heathland communities," Trends in Ecology and Evolution, vol. 14, pp. 215-222, 1999.

[14] S. Tandy, H. L. Wallace, D. L. Jones, M. A. Nason, J. C. Williamson, and J. R. Healey, "Can a mesotrophic grassland community be restored on a post-industrial sandy site with compost made from waste materials?" Biological Conservation, vol. 144, no. 1, pp. 500-510, 2011.

[15] J. C. García-Gil, C. Plaza, P. Soler-Rovira, and A. Polo, "Longterm effects of municipal solid waste compost application on soil enzyme activities and microbial biomass," Soil Biology and Biochemistry, vol. 32, no. 13, pp. 1907-1913, 2000.

[16] M. Odlare, V. Arthurson, M. Pell, K. Svensson, E. Nehrenheim, and J. Abubaker, "Land application of organic waste-effects on the soil ecosystem," Applied Energy, vol. 88, no. 6, pp. 2210$2218,2011$.

[17] C. Crecchio, M. Curci, R. Mininni, P. Ricciuti, and P. Ruggiero, "Short-term effects of municipal solid waste compost amendments on soil carbon and nitrogen content, some enzyme activities and genetic diversity," Biology and Fertility of Soils, vol. 34, no. 5, pp. 311-318, 2001.

[18] A. Pérez-Piqueres, V. Edel-Hermann, C. Alabouvette, and C. Steinberg, "Response of soil microbial communities to compost amendments," Soil Biology and Biochemistry, vol. 38, no. 3, pp. 460-470, 2006.

[19] V. Illera, I. Walter, P. Souza, and V. Cala, "Short-term effects of biosolid and municipal solid waste applications on heavy metals distribution in a degraded soil under a semi-arid environment," Science of the Total Environment, vol. 255, no. 1-3, pp. 29-44, 2000.

[20] M. B. McBride, "Toxic metals in sewage sludge-amended soils: has promotion of beneficial use discounted the risks?" Advances in Environmental Research, vol. 8, no. 1, pp. 5-19, 2003.

[21] S. R. Smith, "A critical review of the bioavailability and impacts of heavy metals in municipal solid waste composts compared to sewage sludge," Environment International, vol. 35, no. 1, pp. 142-156, 2009.

[22] F. Martínez, M. A. Casermeiro, D. Morales, G. Cuevas, and I. Walter, "Effects on run-off water quantity and quality of urban organic wastes applied in a degraded semi-arid ecosystem," Science of the Total Environment, vol. 305, no. 1-3, pp. 13-21, 2003.
[23] T. K. Udeigwe, P. N. Eze, J. M. Teboh, and M. H. Stietiya, "Application, chemistry, and environmental implications of contaminant-immobilization amendments on agricultural soil and water quality," Environment International, vol. 37, no. 1, pp. 258-267, 2011.

[24] V. E. Cabrera, L. J. Stavast, T. T. Baker et al., "Soil and runoff response to dairy manure application on New Mexico rangeland," Agriculture, Ecosystems and Environment, vol. 131, no. 3-4, pp. 255-262, 2009.

[25] R. A. Schoof and D. Houkal, "The evolving science of chemical risk assessment for land-applied biosolids," Journal of Environmental Quality, vol. 34, no. 1, pp. 114-121, 2005.

[26] C. E. Elzinga, D. W. Salzer, and J. W. Willoughby, "Field techniques for measuring vegetation," in Measuring and Monitoring Plant Populations, BLM Technical Reference, 1998.

[27] R. O. Miller, J. Kotuby-Amacher, and J. B. Rodriguez, "Western States Laboratory Proficiency Testing Program, Soil and Plant Analytical Methods," Version 4.00, 1997.

[28] J. R. Sims and V. A. Haby, "The colorimetric determination of soil organic matter," Soil Science, vol. 112, pp. 137-141, 1971.

[29] U.S. E.P.A, Test Methods for Evaluating Solid Waste, Physical/Chemical Methods, vol. SW-846, 3rd edition, 1986.

[30] ASL, "Laboratory Quality Management Plan," University of Idaho Analytical Sciences Laboratory, University of Idaho, Moscow, Idaho, USA, 2003.

[31] SAS, “SAS OnlineDoc," version 9.1.3, SAS Institute Inc., Cary, NC, USA, 2004.

[32] S. Davis, "Regulated metals: the rule of 20," Pollution Prevention Institute, Kansas SBEAP, Kansas State University, 2001.

[33] R. L. Mahler, "Northern Idaho Fertilizer Guide, Legume and Legume-Grass Pastures," CIS 851, University of Idaho Agricultural Experiment Station, 2005.

[34] S. L. McGeehan, "Impact of available nitrogen in mine site revegetation: a case study in the Coeur d'Alene (Idaho) mining district," Communications in Soil Science and Plant Analysis, vol. 40, no. 1-6, pp. 82-95, 2009.

[35] D. M. Sullivan, S. C. Fransen, C. G. Cogger, and A. I. Bary, "Biosolids and dairy manure as nitrogen sources for prairiegrass on a poorly drained soil," Journal of Production Agriculture, vol. 10, no. 4, pp. 589-596, 1997.

[36] B. L. Miller, D. B. Parker, J. M. Sweeten, and C. Robinson, "Response of seven crops and two soils to application of beef cattle feedyard effluent," Transactions of the American Society of Agricultural Engineers, vol. 44, no. 2, pp. 309-315, 2001.

[37] M. B. Robinson, P. J. Polglase, and C. J. Weston, "Loss of mass and nitrogen from biosolids applied to a pine plantation," Australian Journal of Soil Research, vol. 40, no. 6, pp. 10271039, 2002.

[38] M. B. Robinson and H. Röper, "Volatilisation of nitrogen from land applied biosolids," Australian Journal of Soil Research, vol. 41, no. 4, pp. 711-716, 2003.

[39] C. Mendoza, N. W. Assadian, and W. Lindemann, "The fate of nitrogen in a moderately alkaline and calcareous soil amended with biosolids and urea," Chemosphere, vol. 63, no. 11, pp. 1933-1941, 2006.

[40] T. D. Whitson, Weeds of the West, University of Wyoming Press, 5th edition, 1999.

[41] Z. Q. Zhang, W. S. Shu, C. Y. Lan, and M. H. Wong, "Soil seed bank as an input of seed source in revegetation of lead/zinc mine tailings," Restoration Ecology, vol. 9, no. 4, pp. 378-385, 2001.

[42] D. F. Polster, J. Soll, and J. Myers, "Managing northwest invasive vegetation," in Restoring the Pacific Northwest: The Art 
and Science of Ecological Restoration in Cascadia, D. Apostol and M. Sinclair, Eds., Island Press, 2006.

[43] H. L. Carlson and J. E. Hill, "Wild oat (Avena fatua) competition with spring wheat: effects of nitrogen fertilization," Weed Science, vol. 34, pp. 29-33, 1985.

[44] B. Jørnsgård, K. Rasmussen, J. Hill, and J. L. Christiansen, "Influence of nitrogen on competition between cereals and their natural weed populations," Weed Research, vol. 36, no. 6, pp. 461-470, 1996.

[45] S. D. Wilson and D. Tilman, "Components of plant competition along an experimental gradient of nitrogen availability," Ecology, vol. 72, no. 3, pp. 1050-1065, 1991.

[46] T. K. Rajaniemi, "Why does fertilization reduce plant species diversity? Testing three competition-based hypotheses," Journal of Ecology, vol. 90, no. 2, pp. 316-324, 2002.

[47] P. Pysek and J. Leps, "Response of a weed community to nitrogen fertilization: a multivariate analysis," Journal of Veterinary Science, vol. 2, pp. 237-244, 1991. 

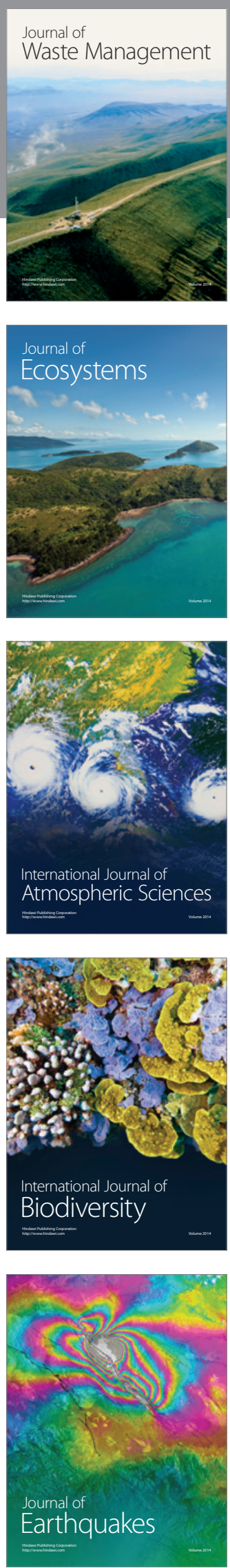
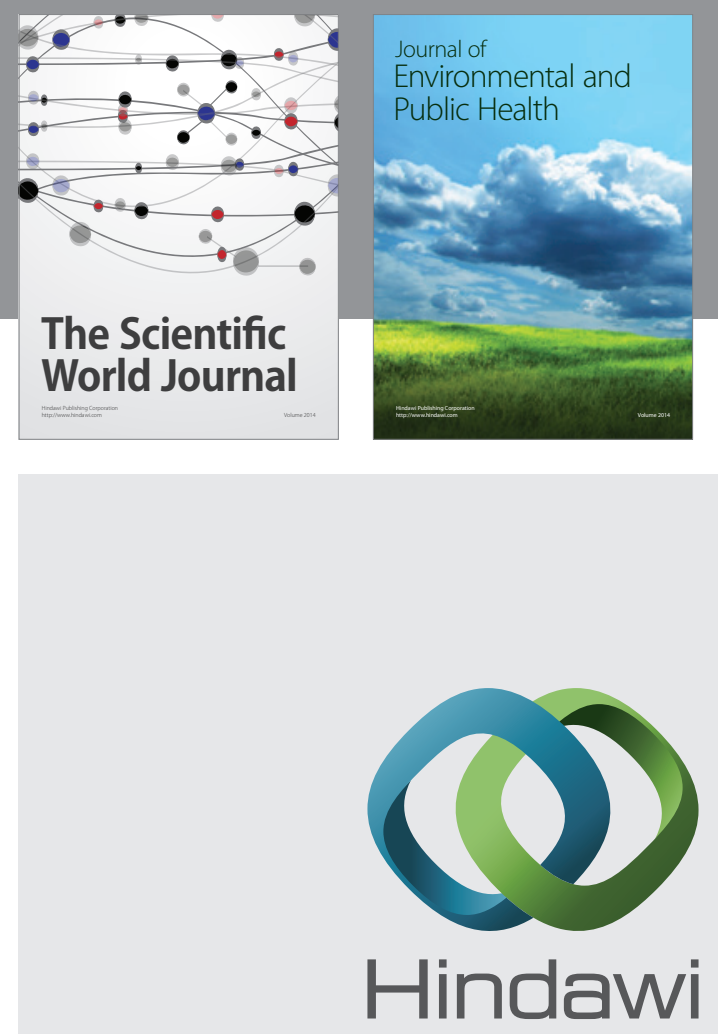

Submit your manuscripts at

http://www.hindawi.com
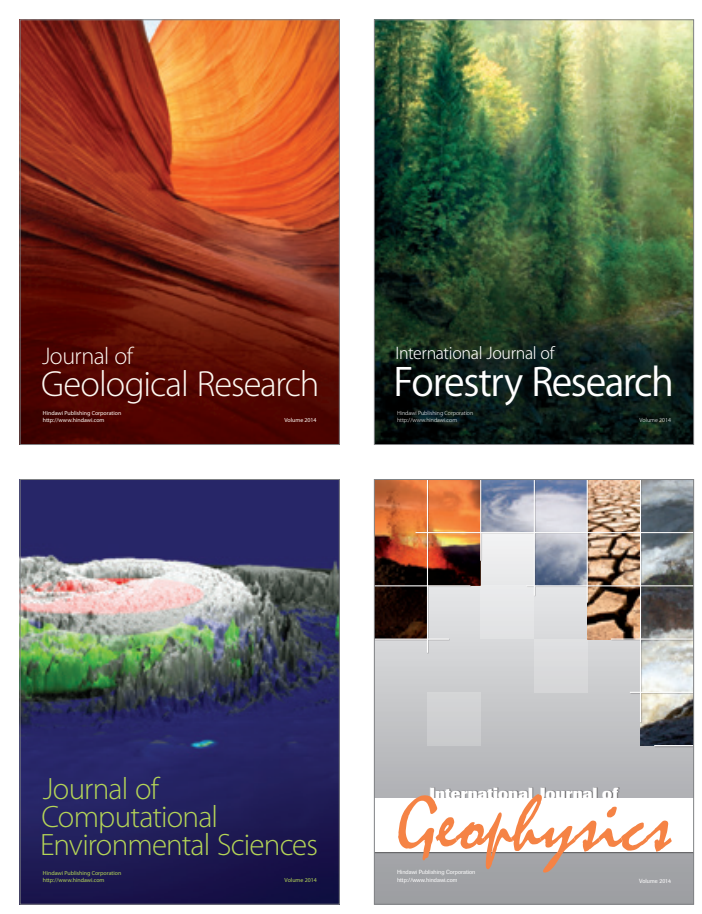
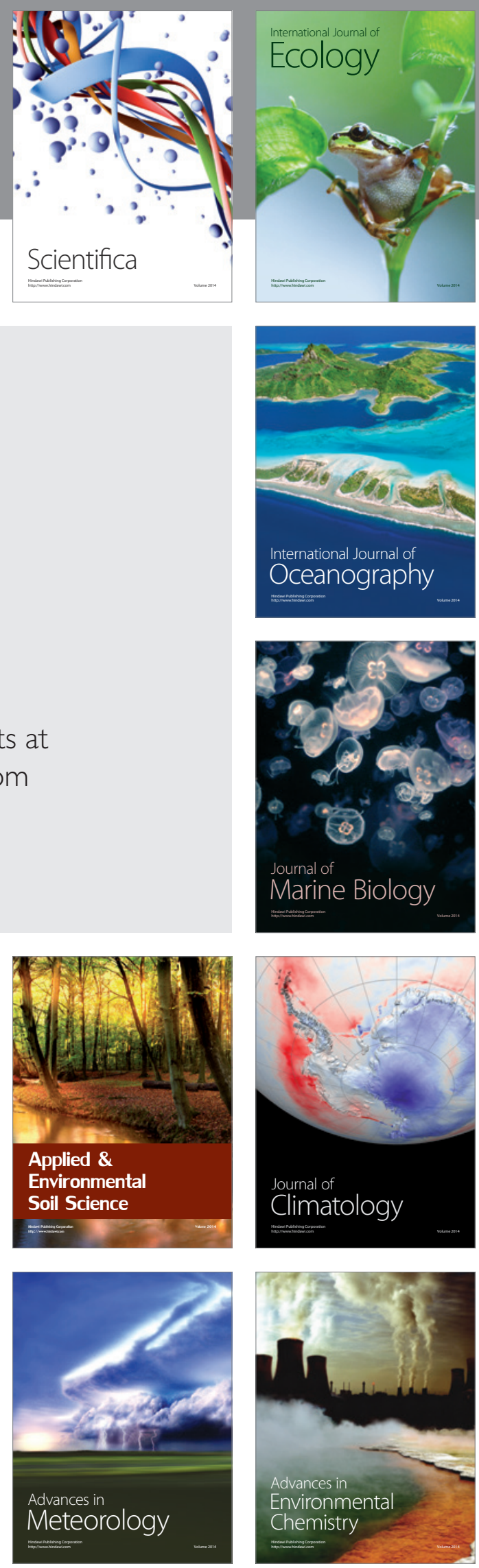